\title{
PERILAKU KONSUMSI SUSU PADA IBU HAMIL
}

\author{
(Milk Consumption Behavior of Pregnant Women) \\ Mustika Nilam Sari ${ }^{1}$, Retnaningsih ${ }^{2}$
}

\begin{abstract}
Pregnant woman with her physiological state is a potential group as milk consumer. The aimed of this research was to study milk consumption behavior among pregnant women. Sampling technique used accidental sampling and choose 300 pregnant women as samples. All data was collected by interview using questionnaire. Inferential statistics included Chi Square and Rank-Spearman Correlation were used for analyzing. The milk forms which consumed include powder, condensed and fresh milk. Most of milk product consumed by samples had label, except for fresh milk. Supermarket as a place to buy was chosen by most of the samples. Nutrition fact was the main attribute concerned in choosing and buying milk. Most of samples (85.0\%) consumed milk for health reason. Milk consumption frequency only had significant positive correlation with knowledge level and household expenditure. Amount of milk consumption had significant positive correlation with education, nutrition knowledge of mother and household expenditure; but had significant negative correlation with family size. Education had correlation with kind, form, main attribute of milk and place to buy milk. Milk expenditure correlated with kind and form, main attribute of, and reason to consume milk. Income correlated with kind, form of and place to buy milk.
\end{abstract}

Key Words: milk consumption, food behavior, pregnant women

\section{PENDAHULUAN}

Menurut Kantor Meneg UPW (1996), pendekatan untuk pembangunan SDM adalah peningkatan kualitas mulai sejak pembuahan, bayi dalam kandungan, anak, remaja, ibu sampai menjadi lansia. Oleh karena itu peningkatan kesehatan dan kesejahteraan ibu dan anak merupakan faktor paling strategis, sebab tingkat kecerdasan anak ditentukan oleh derajat gizi calon ibu dan gizi ibu selama kehamilan.

Masa kehamilan merupakan periode yang sangat menentukan kualitas SDM di masa depan, karena tumbuh kembang anak sangat ditentukan oleh kondisinya saat masa janin dalam kandungan. Jika keadaan kesehatan dan status gizi ibu hamil baik, maka janin yang dikandungnya akan baik juga dan keselamatan ibu waktu melahirkan akan terjamin. Tujuan tersebut dapat direalisasikan dengan memenuhi kecukupan gizi. Apabila kecukupan akan energi dan protein telah terpenuhi, maka kecukupan zat-zat lainnya umumnya telah terpenuhi pula atau sekurangkurangnya tidak terlalu sukar untuk memenuhinya (Khumaidi 1994).

Siswono (2001) mengungkapkan bahwa produksi susu nasional pada tahun 1999 mencapai 436 ribu ton, pada tahun 2000 mengalami peningkatan hingga 497.87 ribu ton. Untuk konsumsi susu di Indonesia terus meningkat. Pada tahun 2000 mencapai 1,537 ton dan di tahun 2001 meningkat menjadi 1,869 ton. Dapat dikatakan hasil produksi susu dalam negeri tidak mencukupi jumlah konsumsi susu nasional sehingga Indonesia masih membutuhkan impor susu. Data Biro Pusat Statistik (BPS) pada tahun 1999 tercatat impor susu sebanyak 55,048 ton dengan harga US\$ 80.7 juta. Dengan besarnya permintaan susu pada tahun 2001 dapat diperkirakan bahwa konsumsi susu pada masyarakat Indonesia setiap harinya relatif tinggi. Ibu hamil dengan kondisi fisiologisnya merupakan kelompok potensial sebagai konsumen susu, sehingga diperlukan penelitian tentang perilaku 
konsumsi susu pada ibu hamil dalam kaitannya dengan pemenuhan kebutuhan gizi yang sesuai dengan daftar kecukupan gizi yang dianjurkan dan seberapa besar kontribusi zat gizi susu terhadap kecukupan yang dianjurkan.

Tujuan penelitian ini adalah untuk mengetahui karakteristik individu (umur, pendidikan, pengetahuan gizi tentang susu, pekerjaan, pengeluaran per bulan untuk susu, dan sumber informasi), karakteristik keluarga (besar keluarga dan pendapatan keluarga), dan karakteristik produk (jenis, bentuk, harga, dan label) susu yang dikonsumsi oleh ibu hamil, mengetahui perilaku konsumsi susu pada ibu hamil (jenis, bentuk, frekuensi, jumlah, tempat pembelian, atribut utama yang paling diperhatikan dalam membeli dan alasan mengkonsumsi susu), dan mengetahui hubungan antara karakteristik individu dengan perilaku konsumsi susu.

\section{METODE PENELITIAN}

Tempat dan Waktu Penelitian

Disain penelitian ini adalah Cross Sectional Study, karena data dikumpulkan pada satu waktu dan tidak berkelanjutan. Penelitian dilakukan di Kota Bogor, Jawa Barat, dengan pertimbangan laju pertumbuhan penduduk dari tahun 2000 ke tahun 2001 sebesar $6.38 \%$ (BPS 2001), serta jumlah ibu hamil pada tahun 2002 di Kota Bogor adalah 20.024 orang yaitu $2.6 \%$ dari jumlah penduduk (Dinkes, 2002). Pengambilan data dilakukan selama dua bulan.

\section{Cara Pemilihan Contoh}

Contoh dalam penelitian ini adalah ibu hamil yang sedang mengkonsumsi susu minimal satu kali dalam satu bulan terakhir. Penentuan lokasi penelitian ini dilakukan secara sengaja atau purposive sampling (Singarimbun dan Effendi 1991), berdasarkan kesediaan pihak Rumah
Sakit, Puskesmas, Klinik Dokter Spesialis Kandungan, maupun Klinik Bersalin dan klub senam ibu hamil sebagai tempat penelitian. Pengambilan contoh dilakukan dengan menggunakan metode aksidental (accidental sampling) yakni suatu teknik penentuan sampel berdasarkan kebetulan, yaitu siapa saja yang ditemukan secara kebetulan dan memenuhi kriteria yang ditentukan (Sugiono 2000).

Pada prinsipnya, dengan aksidental sampling ini peneliti tidak dibatasi dalam memilih contoh selain batasan kriteria. Dimanapun peneliti bertemu dengan calon contoh yang memenuhi kriteria dan calon contoh bersedia diwawancarai, maka pada saat itu wawancara dapat dilakukan (Black dan Champion 1999).

Penelitian ini mengambil 300 orang ibu hamil sebagai contoh. Untuk mendapatkan 300 contoh telah ditemui sebanyak 453 orang ibu hamil dimana sebanyak 352 orang (77.7\%) adalah ibu hamil yang sedang mengkonsumsi susu dan 101 orang (22.3\%) adalah ibu hamil yang tidak mengkonsumsi susu. Bila diamati lebih lanjut dari 352 orang ibu hamil (77.7\%) yang sedang mengkonsumsi susu, sebanyak 52 orang (14.8\%) tidak bersedia berpartisipasi dalam penelitian dan sebanyak 300 orang (85.2\%) bersedia berpartisipasi dalam penelitian.

Jenis dan Cara Pengumpulan Data Jenis data yang dikumpulkan meliputi data primer dan data sekunder. Data primer yang diambil meliputi karakteristik individu (umur, pendidikan, pengetahuan gizi tentang susu, pekerjaan, pengeluaran per bulan untuk susu, dan sumber informasi), karakteristik keluarga (besar keluarga dan pendapatan keluarga), dan perilaku konsumsi susu (konsumsi: jenis, bentuk, frekuensi, jumlah konsumsi, tempat pembelian, atribut utama yang dipertimbangkan dan alasan mengkonsumsi susu) 
dikumpulkan dengan wawancara menggunakan kuesioner. Data sekunder meliputi: karakteristik produk (jenis, bentuk, harga, dan label) dicatat dari label produk yang beredar di pasaran, sedangkan untuk data keadaan umum tempat penelitian dicatat dari kantor BPS dan Dinkes Kota Bogor.

Pengolahan dan Analisis Data

Pengolahan data dilakukan dengan membuat kategori pada peubah karakteristik individu (umur, pendidikan, pengetahuan gizi tentang susu, pekerjaan, pengeluaran per bulan untuk susu, dan sumber informasi), karakteristik keluarga (besar keluarga dan pendapatan keluarga), dan perilaku konsumsi susu (konsumsi: jenis, bentuk, frekuensi, jumlah konsumsi, tempat pembelian, atribut utama yang dipertimbangkan dan alasan mengkonsumsi susu).

Data-data yang diperoleh diolah dan dianalisis secara deskriptif. Analisis statistika deskriptif dilakukan pada peubah karakteristik contoh (umur, pendidikan, pengetahuan gizi tentang susu, pekerjaan, pengeluaran per bulan untuk susu, dan sumber informasi) dan karakteristik keluarga (besar keluarga dan pendapatan keluarga), serta karakteristik produk (jenis, bentuk, harga, dan label) dan data demografi Kota Bogor). Analisis statistika inferensial digunakan untuk melihat hubungan antara karakteristik contoh dan karakteristik keluarga dengan perilaku konsumsi menggunakan uji Chi Square (untuk data nominal dan ordinal) dan korelasi Rank-Spearman (untuk data ordinal). Pengolahan dan analisis data menggunakan komputer dengan Statistical Program for Social Science (SPSS) 10.0 for Window.

\section{HASIL DAN PEMBAHASAN}

Karakteristik Contoh

Umur. Menurut Kotler (1999) usia dapat mempengaruhi selera seseorang terhadap barang dan jasa.
Umur contoh berkisar antara 18 - 45 tahun dengan rata-rata 28 tahun. Sebagian besar contoh (87.0\%) berusia $20-35$ tahun. Hal ini menunjukkan sebagian besar contoh yang tidak beresiko tinggi terhadap kehamilannya. Terdapat 17 orang (5.7\%) ibu hamil yang berusia dibawah 20 tahun.

Tingkat Pendidikan. Tingkat pendidikan contoh bervariasi dari tamat SD sampai dengan pasca sarjana. Persentase terbesar contoh (54\%) mempunyai tingkat pendidikan sedang (SLTP/SLTA), Diploma/S1, S2, S3 (39\%) dan sisanya (7\%) mempunyai tingkat pendidikan rendah (SD).

Pengetahuan Tentang Susu. Pengetahuan gizi tentang susu secara umum tersebar pada kelompok pengetahuan tinggi dan sedang. Hal ini sesuai dengan tingkat pendidikan contoh yang banyak tersebar pada tingkat pendidikan

tinggi dan sedang pula. Sedang untuk tingkat pengetahuan gizi rendah hanya terdapat sebagian kecil saja dari kedua kelompok tersebut. Dari pertanyaan-pertanyaan tentang susu, contoh memahami tentang kegunaan susu secara umum.

Persentase terbesar contoh (55.7\%) memiliki skor pengetahuan tentang susu pada kategori tinggi $(>80)$, selanjutnya berada pada kategori sedang (60-80) sebesar $43.0 \%$ dan pada kategori rendah $(<60)$ sebesar $1.3 \%$. Hasil ini menunjukkan bahwa persentase contoh yang memiliki pengetahuan gizi tentang susu yang tinggi lebih banyak daripada yang berpendidikan rendah. Keadaan ini diduga berhubungan dengan tingkat pendidikan contoh yang umumnya lebih banyak yang berpendidikan sedang sampai tinggi daripada yang berpendidikan rendah.

Pekerjaan. Dalam penelitian ini persentase terbesar contoh adalah sebagian ibu rumahtangga (70.3\%). karyawan swasta/BUMN (12.0\%), 
PNS (11.0\%), wiraswasta (4.3\%), dan 2.3\% mahasiswa.

Pengeluaran untuk susu. Pengeluaran untuk susu dapat diketahui dengan menghitung jumlah rupiah yang dikeluarkan untuk membeli susu selama sebulan. Contoh memiliki pengeluaran susu per kapita per bulan yang bervariasi dengan kisaran antara Rp 10,000.00 hingga Rp 460,000.00 dengan ratarata pengeluaran $\mathrm{Rp} 102,114.00$. Ada kecende-rungan semakin tinggi pendapatan, pengeluaran untuk susu juga semakin tinggi. Sebanyak besar (61.3\%) contoh berpendapatan tinggi memiliki tingkat pengeluaran untuk susu yang tinggi, $54.9 \%$ contoh berpendapatan rendah, pengeluaran untuk susu sedang, dan persentase terbesar contoh berpendapatan rendah pengeluaran untuk susu sedang (36.8\%) dan rendah (36.8\%).

Sumber Informasi. Dari penelitian ini diketahui bahwa sumber informasi produk dapat diklasifikasikan berdasarkan personal dan impersonal. Informasi mengenai susu diperoleh dari media massa, teman dan keluarga, distributor dan tenaga kesehatan. Hasil penelitian menunjukkan bahwa pada umumnya contoh mendapatkan informasi tentang susu dari media massa (67.0\%). Disusul oleh sumber informasi melalui teman dan keluarga $(19.7 \%)$, dari tenaga kesehatan (7.3\%) dan sisanya (6.0\%) diperoleh contoh melalui informasi yang ada dalam toko (pusat perbelanjaan).

\section{Karakteristik Keluarga}

Besar Keluarga. Sebagian besar contoh memiliki jumlah anggota keluarga kecil. yaitu sebanyak 241 keluarga (80.3\%) dan keluarga sedang 44 keluarga (14.7\%). Sedangkan yang termasuk dalam keluarga besar sebanyak 15 keluarga (5.0\%).
Pendapatan. Hasil penelitian menunjukkan bahwa pendapatan per kapita per bulan keluarga contoh berkisar antara Rp 40,000.00 hingga Rp 4,000,000.00 dengan rata-rata pendapatan Rp 654,647.00. Sebagian besar $(76.7 \%)$ contoh berada pada tingkat pendapatan tinggi, disusul oleh $17.0 \%$ contoh pada tingkat pendapatan sedang, dan sisanya $6.3 \%$ contoh berada pada tingkat pendapatan rendah.

\section{Karakteristik Produk}

Bentuk dan Merek Susu. Susu yang dikonsumsi dalam sebulan terakhir oleh contoh bervariasi bentuk dan mereknya. Bentuk susu yang dikonsumsi meliputi susu bubuk, susu kental manis, dan susu cair. Merek susu yang dikonsumsi contoh ada 14 merek. Dari 14 merek tersebut, merek susu yang khusus untuk ibu hamil ada 7 merek yaitu An Mum, Enfamama, Lactamil, Lactona, Nutricia Bunda, Prenagen, dan Sustagen Mama. Untuk merek susu yang bukan khusus untuk ibu hamil ada 7 merek yaitu Bendera (terdiri dari susu bubuk dan susu kental manis), Dancow (terdiri dari Dancow Instant, Dancow Full Cream, dan Dancow Coklat), Milo, Kedelai, Ultra, Prolene, dan Susu Segar.

Harga. Harga susu yang dikonsumsi contoh berkisar antara Rp 13.34 hinga Rp 111.33 per gramnya (Tabel 1). Apabila dilihat dari rata-rata biaya yang dikeluarkan untuk membeli susu per bulan per gram berdasarkan bentuknya, maka harga tertinggi terdapat pada susu bubuk dengan harga $R p$ 111.33, kemudian bentuk segar $\mathrm{Rp} 28.00$, bentuk cair Rp 18.00, dan bentuk kental Rp 13.34. Rata-rata biaya yang dikeluarkan dalam sebulan untuk membeli susu sebesar Rp 102.11. 
Tabel 1. Daftar Harga Susu Per Gram dan Zat Gizi yang Terkandung dalam Susu (Rp/Satuan Zat Gizi)

\begin{tabular}{|c|c|c|c|c|c|c|c|c|c|c|}
\hline $\begin{array}{l}\mathbf{N} \\
\mathbf{O}\end{array}$ & $\begin{array}{l}\text { Merek } \\
\text { Susu }\end{array}$ & $\begin{array}{c}\text { Harg } \\
\text { a } \\
(\mathrm{Rp} / \mathrm{g} \\
\mathrm{f}\end{array}$ & $\begin{array}{c}\text { Harga } \\
\text { Energi } \\
\text { (Rp/Kk } \\
\text { al } \\
\text { Energi } \\
\text { ) }\end{array}$ & $\begin{array}{l}\text { Harga } \\
\text { Protei } \\
\text { n } \\
\text { (Rp/g } \\
\text { Protei } \\
\text { n) }\end{array}$ & $\begin{array}{c}\text { Harg } \\
\text { a Vit. } \\
\text { A } \\
\text { (Rp/I } \\
\text { U } \\
\text { Vit. } \\
\text { A) }\end{array}$ & $\begin{array}{l}\text { Harga } \\
\text { Vit C } \\
\text { (Rp/m } \\
\text { g Vit } \\
\text { C) }\end{array}$ & $\begin{array}{l}\text { Harga } \\
\text { As. } \\
\text { Folat } \\
\text { (Rp/m } \\
\text { cg As. } \\
\text { Folat }\end{array}$ & $\begin{array}{c}\text { Harga } \\
\text { Ca } \\
(\mathrm{Rp} / \mathrm{m} \\
\mathrm{g} \mathrm{Ca})\end{array}$ & $\begin{array}{l}\text { Harga } \\
\text { Fe } \\
\text { (Rp/m } \\
\text { g Fe) }\end{array}$ & $\begin{array}{l}\text { Harga } \\
\text { lod } \\
\text { (Rp/m } \\
\text { cg lod) }\end{array}$ \\
\hline \multicolumn{11}{|c|}{ Khusus Ibu Hamil } \\
\hline 1 & $\begin{array}{l}\text { Prenage } \\
n\end{array}$ & 89.18 & 23.59 & 343.00 & 2.68 & 55.74 & 13.38 & 8.92 & 287.68 & 53.72 \\
\hline 2 & Lactamil & 43.24 & 10.34 & 354.35 & 1.66 & 27.03 & 5.21 & 4.32 & 172.86 & 28.83 \\
\hline 3 & $\begin{array}{l}\text { Nutricia } \\
\text { Bunda }\end{array}$ & 91.33 & 23.24 & 73.65 & 5.54 & $\begin{array}{r}5,372 \\
34\end{array}$ & 18.27 & 9.13 & 304.43 & 73.06 \\
\hline 4 & $\begin{array}{l}\text { Enfama } \\
\text { ma }\end{array}$ & $\begin{array}{r}111.3 \\
3\end{array}$ & 28.77 & 428.19 & $\begin{array}{r}42.8 \\
2\end{array}$ & 236.87 & 18.55 & 9.28 & $\begin{array}{r}1,325 \\
36\end{array}$ & 113.60 \\
\hline 5 & An Mum & 86.00 & 20.48 & 262.19 & $\begin{array}{r}11.4 \\
5\end{array}$ & 107.50 & 9.55 & 6.47 & 430.00 & 91.49 \\
\hline 6 & $\begin{array}{l}\text { Sustage } \\
\text { n Mama }\end{array}$ & 83.75 & 22.04 & 359.44 & 2.62 & 348.96 & 26.17 & 10.74 & $\begin{array}{r}1,179 \\
58\end{array}$ & 139.58 \\
\hline 7 & Lactona & 37.50 & 31.17 & 595.24 & 3.79 & 62.50 & 31.25 & 18.38 & $\begin{array}{r}2,791 . \\
67\end{array}$ & 125.00 \\
\hline \multicolumn{11}{|c|}{ Bukan Khusus Ibu Hamil } \\
\hline 8 & Prolene & 52.75 & 13.88 & 171.82 & 1.88 & 47.95 & 7.23 & 2.93 & 251.19 & 138.82 \\
\hline 9 & Milo & 36.00 & 9.00 & 300.00 & - & 60.00 & - & 6.00 & 342.86 & - \\
\hline \multirow[t]{3}{*}{10} & $\begin{array}{l}\text { - Danco } \\
\text { w } \\
\text { Fullcre } \\
\text { am }\end{array}$ & 38.25 & 7.54 & 149.65 & 2.13 & 73.77 & 19.12 & 4.11 & 382.50 & 73.77 \\
\hline & $\begin{array}{l}\text { - Danco } \\
\text { w } \\
\text { Coklat }\end{array}$ & 39.31 & 8.83 & 341.83 & 3.02 & 98.28 & 112.31 & 4.52 & 436.78 & - \\
\hline & $\begin{array}{l}\text { - Danco } \\
\text { w } \\
\text { Instant }\end{array}$ & 38.74 & 7.64 & 151.92 & 2.15 & 74.78 & 19.39 & 4.17 & 387.79 & 74.79 \\
\hline 11 & $\begin{array}{l}\text { Kedelai } \\
\text { Instant }\end{array}$ & 37.80 & 18.44 & 216.00 & - & 378.00 & - & $\begin{array}{r}151.2 \\
0\end{array}$ & $\begin{array}{r}1,080 . \\
00\end{array}$ & - \\
\hline \multirow[t]{2}{*}{12} & $\begin{array}{l}\text { - Bender } \\
\text { a } \\
\text { Bubuk }\end{array}$ & 35.73 & 7.31 & 142.92 & 2.38 & 92.90 & 238.20 & 1.85 & 678.87 & 132.73 \\
\hline & $\begin{array}{l}\text { - Bender } \\
\text { a Susu } \\
\text { Kental } \\
\text { Manis }\end{array}$ & 13.34 & 4.08 & 187.62 & 1.78 & - & - & 4.92 & - & - \\
\hline 13 & $\begin{array}{l}\text { Ultra } \\
\text { Milk }\end{array}$ & 18.88 & 10.49 & 236.00 & 1.64 & - & - & 0.98 & - & - \\
\hline 14 & Segar & 28.00 & 45.90 & 875.00 & $\begin{array}{r}62.2 \\
2\end{array}$ & $\begin{array}{r}2,800 . \\
00\end{array}$ & - & 19.58 & $\begin{array}{r}1,647 . \\
06\end{array}$ & - \\
\hline
\end{tabular}

Dari Tabel 1 terlihat bahwa susu khusus untuk ibu hamil lebih mahal dari susu bukan untuk ibu hamil. Hal ini diduga karena susu khusus untuk ibu hamil biasanya diperkaya dengan vitamin dan mineral untuk memenuhi kecukupan zat gizi ibu hamil.

Label. Keterangan tentang halal, nama dan alamat produsen, komposisi bahan yang digunakan, berat bersih, cara penggunaan dan penyimpanan, nomor pendaftaran pangan, kode produksi, informasi komposisi nilai gizi serta tanggal, bulan dan tahun kadaluarsa telah tercantum pada label susu yang dikonsumsi contoh, kecuali pada produk susu segar yang tidak mencantumkan semua keterangan diatas. Namun pada susu bubuk kedelai instant dan susu cair Ultra hanya keterangan halal yang tidak 
dicantumkan, padahal dalam UU RI No. 7 tentang Pangan disebutkan bahwa keterangan halal untuk produk pangan sangat penting bagi masyarakat Indonesia yang mayoritas memeluk agama Islam.

\section{Perilaku Konsumsi Susu}

Merek dan Bentuk Susu. Merek dan bentuk susu yang dikonsumsi oleh contoh bervariasi. Sebagian besar contoh $(98.3 \%)$ mengkonsumsi susu dalam bentuk bubuk (Tabel 2). Hal ini diduga karena kebanyakan produk susu ibu hamil diproduksi dalam bentuk susu bubuk. Seperti halnya yang dikemukakan oleh Siswono (2001) susu bubuk menempati urutan pertama dalam tingkat produksinya dibanding susu jenis lainnya, seperti susu kental manis, atau susu murni. Hal ini disebabkan luasnya jaringan pasar yang dikuasai oleh susu bubuk.

Tabel 2. Sebaran Contoh menurut Bentuk Susu yang Dikonsumsi

\begin{tabular}{|l|l|r|r|}
\hline \multirow{2}{*}{ No } & \multirow{2}{*}{ Bentuk Susu } & \multicolumn{2}{|c|}{ Jumlah } \\
\cline { 3 - 4 } & & \multicolumn{1}{|c|}{$\mathbf{n}$} & \multicolumn{1}{c|}{$\%$} \\
\hline 1. & Bubuk & 295 & 98.3 \\
2. & Kental & 2 & 0.7 \\
3. & Cair & 0 & 0.0 \\
4. & Susu Segar & 1 & 0.3 \\
5. & Kombinasi Bubuk & 2 & 0.7 \\
& + Cair & & \\
\hline \multicolumn{2}{|l|}{ Total } & 300 & 100.0 \\
\hline
\end{tabular}

Contoh yang mengkonsumsi susu kental manis (SKM) sebanyak $0.7 \%$, karena harganya yang relatif murah (Rp 13.34/g) dibanding susu cair (Rp $18.88 / g$ ), susu segar (Rp 28.00/g), dan susu bubuk (Rp 35.73/g$111.33 / \mathrm{g}$ ). Susu kental manis (SKM) memiliki kandungan gula yang tinggi (43-48\%) dibanding susu lainnya sehingga dapat berfungsi sebagai sumber kalori dan bahan pengawet.

Dari Tabel 3 dapat dilihat bahwa merek susu yang paling banyak dikonsumsi contoh adalah Prenagen (62.8\%), disusul oleh Lactamil (16.7\%). Hal ini diduga karena merek susu tersebut harganya relatif terjangkau (Rp 89.18/g) dan rasanya yang enak (tidak banyak menimbulkan keluhan terhadap contoh). Sedangkan merek Lactamil, walaupun harganya lebih murah daripada Prenagen, tetapi mempunyai aroma yang sangat kuat, sehingga kurang diminati oleh contoh. Produk susu dengan penambahan Fe dan Ca mempunyai kekhasan dari segi aroma.

Tabel 3. Sebaran Contoh menurut Bentuk dan Merek Susu yang Dikonsumsi

\begin{tabular}{|l|l|r|r|}
\hline \multirow{2}{*}{ No } & \multicolumn{1}{|c|}{ Merek Susu } & \multicolumn{2}{|c|}{ Jumlah } \\
\cline { 3 - 4 } & & $\mathbf{n}$ & \multicolumn{1}{c|}{$\%$} \\
\hline & Susu Khusus Ibu & & \\
1. & Hamil & & \\
2. & Bentuk bubuk: & 1 & 0.1 \\
3. & En Mum & 15 & 4.8 \\
4. & Lnfamama & 3 & 1.0 \\
5. & Lactona & 52 & 16.7 \\
6. & Nutricia Bunda & 8 & 2.6 \\
7. & Prenagen & 196 & 62.8 \\
& Sustagen mama & 7 & 2.2 \\
& & & \\
8. & Susu Bukan Khusus & & \\
9. & Ibu Hamil & 2 & 0.6 \\
& Bentuk bubuk: & 10 & 3.2 \\
& Bendera & 2 & 0.6 \\
10. & Dancow Instant & 2 & 0.6 \\
11. & Dancow Coklat & 1 & 0.1 \\
12. & Dancow Full Cream & 2 & 0.6 \\
& Prolene & 1 & 0.1 \\
13. & Milo & & \\
14 & Kedelai & 1 & 0.1 \\
& Bentuk Cair: & 1 & 0.1 \\
& Ultra & & \\
\hline
\end{tabular}

Sebagian besar (92.3\%) contoh mengkonsumsi susu khusus untuk ibu hamil, disusul oleh contoh yang mengkonsumsi susu bukan untuk ibu hamil (susu biasa) sebanyak 5.7\%, dan sisanya adalah $2.0 \%$ contoh yang mengkonsumsi susu dengan mengkombinasikan antara susu 
khusus untuk ibu hamil dan susu biasa (Tabel 4). Contoh yang mengkonsumsi susu biasa mempunyai alasan kurang suka dengan susu khusus untuk ibu hamil, karena faktor rasa yang kurang enak. Sedangkan contoh yang mengkonsumsi kombinasi susu keduanya (susu khusus ibu hamil dan susu biasa) mempunyai alasan kurang suka dengan susu khusus ibu hamil dan untuk variasi agar tidak bosan.

Tabel 4. Sebaran Contoh berdasarkan Pengelompokan Susu yang Dikonsumsi

\begin{tabular}{|l|l|r|r|}
\hline \multirow{2}{*}{ No } & Pengelompokan & \multicolumn{2}{|c|}{ Jumlah } \\
\cline { 3 - 4 } & \multicolumn{1}{|c|}{ Susu } & \multicolumn{1}{c|}{$\%$} \\
\hline 1. & Susu Khusus Ibu & 277 & 92.3 \\
2. & Hamil & 17 & 5.7 \\
3. & Susu Bukan Untuk & 6 & 2.0 \\
& Ibu Hamil & & \\
& Susu Kombinasi & & \\
& Susu Khusus Ibu & & \\
& Hamil dan Bukan & & \\
& Untuk Ibu Hamil & & \\
\hline Total & 300 & 100.0 \\
\hline
\end{tabular}

Frekuensi dan Jumlah Konsumsi Susu. Frekuensi konsumsi merupakan salah satu cara untuk mengetahui perilaku konsumsi susu dan memberikan gambaran berapa kali contoh mengkonsumsi susu dalam satu bulan. Frekuensi konsumsi susu pada contoh berkisar antara 8.0 kali/bulan-99.0 kali/bulan dengan ratarata sebesar 42.0 kali/bulan. Persentase terbesar contoh mengkonsumsi susu berada pada kategori sering, yakni sebanyak $49.0 \%$, diikuti kategori jarang (31.0\%), dan selebihnya pada kategori sangat sering (20.0\%) (Tabel 5).

Tabel 5. Sebaran Contoh menurut Frekuensi Konsumsi Susu dalam Sebulan

\begin{tabular}{l|l|l} 
No & Frekuensi Konsumsi & Jumlah \\
\hline
\end{tabular}

\begin{tabular}{|l|l|l|l|}
\hline & Susu (kali/bulan) & $\mathrm{n}$ & $\%$ \\
\hline 1. & Jarang $(<30)$ & 93 & 31.0 \\
2. & Sering $(30-60)$ & 147 & 49.0 \\
3. & Sangat Sering $(>60)$ & 60 & 20.0 \\
\hline \multicolumn{2}{|l|}{ Total } & 300 & 100.0 \\
\hline
\end{tabular}

Jumlah susu yang dikonsumsi contoh setiap bulan bervariasi dari $230 \mathrm{~g} / \mathrm{bl}$ hingga $4225 \mathrm{~g} / \mathrm{bl}$ dengan rata-rata $1288 \mathrm{~g} / \mathrm{bl}$. Tabel 6 menunjukkan bahwa sebesar 53.3\% contoh mengkonsumsi susu dalam jumlah sedang (1050-2100 g/bl), disusul oleh contoh yang mengkonsumsi susu dalam jumlah rendah $(<1050 \mathrm{~g} / \mathrm{bl})$ sebesar $38.3 \%$, dan $8.3 \%$ contoh mengkonsumsi susu dalam jumlah tinggi $(>2100 \mathrm{~g} / \mathrm{bl})$.

Tabel 6. Sebaran Contoh menurut Jumlah Konsumsi Susu dalam Sebulan

\begin{tabular}{|l|l|r|r|}
\hline \multirow{2}{*}{ No } & \multicolumn{2}{|l|}{ Jumlah Konsumsi } & \multicolumn{2}{|c|}{ Jumlah } \\
\cline { 3 - 4 } & Susu (g/bulan) & \multicolumn{1}{|c|}{$\mathbf{n}$} & \multicolumn{1}{c|}{$\%$} \\
\hline 1. & Rendah (<1050) & 115 & 38.3 \\
2. & Sedang (1050- & 160 & 53.3 \\
3. & 2100) & 25 & 8.3 \\
& Tinggi (>2100) & & \\
\hline \multicolumn{2}{|l|}{ Total } & 300 & 100.0 \\
\hline
\end{tabular}

Tempat Pembelian. Pembelian susu biasa dilakukan di berbagai tempat yaitu supermarket, pasar, apotik, warung ataupun tukang susu keliling. Persentase terbesar contoh (75.3\%) membeli produk susu di supermarket. Pemilihan tempat pembelian bisa disebabkan oleh berbagai faktor, misalnya kepraktisan, kenyamanan, kedekatan lokasi, kelangkaan produk atau alasan lainnya.

Pembelian di tempat tersebut bisa dijelaskan dengan alasan keamanan, keleluasaan, dan kenyamanan dalam pembelian. Alasan kepraktisan dan dekat dengan rumah bisa menjadi alasan pembelian di toko atau pasar oleh contoh (20.3\%). Sedangkan pembelian pada tukang susu keliling, agen-agen distributor, dan klinik bersalin dilakukan sebanyak 3.0\% contoh. Pembelian pada tukang susu keliling disebabkan karena produk 
susu tersebut tidak hanya untuk susu segar yang siap dikonsumsi. Dan pembelian susu di apotek dilakukan (1.3\%) contoh dengan alasan keamanan dan kepraktisan waktu sambil memeriksakan kehamilan di tempat praktek dokter ataupun rumahsakit bersalin maupun klinik lainnya (Tabel 7)

Tabel 7. Sebaran Contoh menurut Tempat Pembelian Susu

\begin{tabular}{|l|l|r|r|}
\hline \multirow{2}{*}{ No } & \multicolumn{1}{|c|}{ Tempat } & \multicolumn{2}{|c|}{ Jumlah } \\
\cline { 3 - 4 } & Pembelian & \multicolumn{1}{|c|}{$\mathbf{n}$} & \multicolumn{1}{c|}{$\%$} \\
\hline 1. & Supermarket & 266 & 75.3 \\
2. & Pasar & 61 & 20.3 \\
3. & Apotek & 4 & 1.3 \\
4. & Lain-lain & 9 & 3.0 \\
\hline \multicolumn{2}{|l|}{ Total } & 300 & 100.0 \\
\hline
\end{tabular}

Atribut Utama. Persentase terbesar contoh (47.0\%) memilih kandungan gizi sebagai atribut yang paling dipertimbangkan dalam membeli susu. Kemudian $33.7 \%$ contoh memilih manfaat sebagai atribut yang paling diutamakan dalam membeli susu. Data menunjukkan bahwa contoh yang memilih kandungan gizi sebagai atribut yang paling diperhatikan $50.4 \%$ memiliki tingkat pendidikan tinggi. Sedangkan contoh yang memilih manfaat sebagai atribut yang paling diperhatikan $64.7 \%$ memiliki tingkat pendidikan sedang. Selanjutnya disusul oleh atribut rasa (15.7\%), ini berhubungan dengan rasa dari susu yang akan dikonsumsi contoh. Contoh yang memilih atribut rasa $51.1 \%$ memiliki tingkat pendidikan sedang. Sedangkan harga adalah atribut yang paling sedikit dipilih contoh (3.3\%). Contoh yang memilih atribut harga $90 \%$ pada tingkat pendidikan sedang (Tabel 8).

Tabel 8. Sebaran Contoh menurut Atribut yang Paling Diperhatikan dalam Memilih dan Membeli Susu

\begin{tabular}{|l|l|l|l|}
\hline \multirow{2}{*}{ No } & \multirow{2}{*}{ Atribut Utama } & \multicolumn{2}{|c|}{ Jumlah } \\
\cline { 3 - 4 } & & \multicolumn{1}{|c|}{$\mathbf{n}$} & \multicolumn{1}{|c|}{$\%$} \\
\hline 1. & Kandungan gizi & 141 & 47.0 \\
2. & Harga & 10 & 3.3 \\
3. & Rasa & 47 & 15.7 \\
\hline
\end{tabular}

\begin{tabular}{|l|l|l|l|}
\hline 4. & Manfaat & 101 & 33.7 \\
\hline Total & 299 & 100.0 \\
\hline
\end{tabular}

Alasan Mengkonsumsi Susu. Sebagian besar (85.0\%) contoh dalam penelitian ini menyatakan alasan kesehatan, $12.0 \%$ contoh dengan alasan kebiasaan serta 3.0\% contoh dengan alasan kesukaan. Data tersebut menunjukkan bahwa contoh dalam mengkonsumsi susu lebih mementingkan kesehatan daripada faktor lainnya dalam mengkonsumsi susu. Hal ini dapat dimengerti karena kondisi fisiologis contoh yang sedang hamil membutuhkan asupan zat gizi yang lebih tinggi. Sebarannya dapat dilihat pada Tabel 9.

Tabel 9. Sebaran Contoh menurut Alasan Mengkonsumsi Susu

\begin{tabular}{|l|l|r|r|}
\hline \multirow{2}{*}{ No } & Alasan Konsumsi & \multicolumn{2}{|c|}{ Jumlah } \\
\cline { 3 - 4 } & Susu & $\mathrm{n}$ & $\%$ \\
\hline 1. & Kesehatan & 255 & 85.0 \\
2. & Kebiasaan & 36 & 12.0 \\
3. & Kesukaan & 9 & 3.0 \\
\hline Total & 300 & 100.0 \\
\hline
\end{tabular}

Analisis Hubungan Konsumsi Susu dengan Karakteristik Contoh dan Karakteristik Keluarga

Analisis hubungan perilaku konsumsi dengan karakteristik contoh dan karakteristik keluarga dapat dilihat menurut frekuensi, jumlah konsumsi, tempat pembelian, atribut utama, jenis, dan alasan konsumsi susu selama sebulan, hubungan dengan umur, tingkat pendidikan, pengetahuan tentang susu, pekerjaan, pengeluaran untuk susu, sumber informasi, besar keluarga dan pendapatan.

Untuk jenis data ordinal digunakan uji korelasi RankSpearman. Untuk data nominal dan ordinal digunakan uji Chi-Square.

Pendidikan. Hasil uji korelasi Spearman menunjukkan bahwa jumlah konsumsi berhubungan nyata positif dengan tingkat pendidikan. Artinya semakin tinggi tingkat pendidikan maka jumlah konsumsi susu yang dikonsumsi semakin 
meningkat. Hal ini sesuai dengan yang dikemukakan oleh Notoatmodjo (1997) bahwa tingkat pendidikan akan mempengaruhi konsumsi pangan melalui bahan makanan yang lebih baik dalam jumlah dan mutunya dibandingkan yang berpendidikan rendah.

Pengetahuan.

Tingkat pengetahuan gizi tentang susu berhubungan nyata positif dengan frekuensi dan jumlah konsumsi susu. Artinya semakin tinggi tingkat pengetahuan gizi tentang susu maka semakin tinggi juga frekuensi dan jumlah konsumsi susu.

Pengeluaran. Tingkat pengeluaran untuk susu berhubungan nyata positif dengan frekuensi dan jumlah konsumsi. Artinya semakin tinggi pengeluaran contoh untuk susu maka frekuensi dan jumlah konsumsi semakin meningkat.

Pendapatan. Tingkat pendapatan berhubungan nyata positif dengan jumlah konsumsi. Artinya semakin tinggi pendapatan, jumlah konsumsi semakin meningkat.

Besar Keluarga. Hasil uji korelasi Spearman antara karakteristik keluarga dengan perilaku konsumsi menunjukkan bahwa jumlah konsumsi berhubungan nyata negatif dengan besar keluarga. Artinya semakin besar keluarga, semakin rendah jumlah konsumsi.

Pendidikan. Pendidikan contoh tidak berhubungan dengan alasan mengkonsumsi susu $(p>0.05)$. Tetapi pendidikan berhubungan dengan jenis, bentuk, atribut utama yang dipertimbangkan, dan tempat membeli $(p<0.05)$.

Pengeluaran untuk Susu. Hasil uji Chi-Square menunjukkan bahwa pengeluaran untuk susu tidak berhubungan dengan tempat pembelian $\quad(p>0.05), \quad$ tetapi berhubungan dengan jenis dan bentuk susu, atribut utama yang dipertimbangkan, serta alasan konsumsi $(p<0.05)$.
Pendapatan. Pendapatan tidak berhubungan dengan atribut utama yang dipertimbangkan, dan alasan mengkonsumsi susu $(p>0.05)$. Tetapi berhubungan dengan jenis dan bentuk susu, serta tempat pembelian $(p<0.05)$.

\section{SIMPULAN DAN SARAN}

Simpulan

1. Rata-rata responden berumur 28 tahun, sebagian besar ibu rumah tangga dengan latar belakang pendidikan menengah (SLTA/SLTP) dan separuhnya memiliki penegetahuan gizi yang tinggi. Separuh responden mempunyai tingkat pengeluaran susu yang tinggi yaitu lebih dari Rp 80,000.00. Umumnya contoh memperoleh informasi mengenai susu melalui media massa, khususnya iklan televisi. Responden mempunyai jumlah anggota keluarga $\leq 4$ orang. Sebagian besar tingkat pendapatan keluarga per kapita adalah lebih dari Rp 300,000.00.

2. Bentuk susu yang dikonsumsi contoh meliputi susu bubuk, Susu Kental Manis, dan cair. Merek susu yang dikonsumsi contoh ada 14 merek. Harga per gram susu termurah terdapat pada Susu Kental Manis Bendera (Rp 13.34) dan yang termahal terdapat pada susu Enfamama (Rp 111.33). Harga energi termurah terdapat pada Susu Kental Manis Bendera, protein termurah terdapat pada susu Nutricia Bunda, vitamin A dan kalsium termurah terdapat pada susu Ultra. Lactamil mempunyai zat gizi termurah yaitu vitamin $\mathrm{C}$, asam folat, $\mathrm{Fe}$, dan Iodium.

3. Produk susu yang dikonsumsi contoh hampir seluruhnya telah mencantumkan label (keterangan halal, nama dan alamat produsen, komponen bahan yang digunakan, berat badan, informasi komponen nilai gizi serta tanggal, 
bulan, dan tahun kadaluwarsa), kecuali susu segar. Untuk susu Enfamama, susu bubuk kedelai, hanya keterangan halal yang tidak dicantumkan. Susu Ultra tidak mencantumkan keterangan halal dan cara penggunaan serta penyimpanan.

4. Supermarket merupakan tempat pembelian susu yang paling banyak dipilih contoh dan memilih kandungan gizi sebagai atribut utama yang paling diperhatikan dalam memilih dan membeli susu. Sebagian besar contoh mengkonsumsi susu karena alasan kesehatan.

5. Frekuensi konsumsi susu hanya berhubungan nyata positif dengan tingkat pengetahuan dan pengeluaran. Jumlah konsumsi susu berhubungan nyata positif dengan pendidikan, pengetahuan, dan pengeluaran. Jumlah konsumsi berhubungan nyata negatif dengan besar keluarga. Pendidikan berhubungan dengan jenis, bentuk,atribut utama dan tempat pembelian. Pengeluaran untuk susu berhubungan jenis dan bentuk, atribut utama, dan alasan mengkonsumsi susu. Pendapatan berhubungan dengan jenis, bentuk dan tempat pembelian.

\section{Saran}

Untuk dapat memenuhi kebutuhan energi dan zat gizi pada ibu hamil, disarankan untuk mengkonsumsi pangan yang beragam dan minum susu $2 \mathrm{kali} / \mathrm{hr}$. Pemilihan merek susu harus memperhatikan kandungan zat gizi dan harga per satuan zat gizi, serta harus membaca label pada kemasan susu. Informasi tentang jenis, bentuk, dan alasan konsumen mengkonsumsi susu dapat dijadikan pertimbangan bagi produsen dalam pengembangan produk.

\section{DAFTAR PUSTAKA}

[BPS] Badan Pusat Statistik. 2001. Kota Bogor dalam Angka. BPS, Bogor.

Black, J. A \& D. J. Champion. 1999. Metode dan Masalah Penelitian Sosial. Bandung: Refika Aditama.

[Depkes] Departemen Kesehatan RI. 1996 Pedoman Praktis Pemantauan Status Gizi Orang Dewasa. Departemen Kesehatan Republik Indonesia, Jakarta.

Khumaidi. 1994. Bahan Pengajaran Gizi Masyarakat. Jakarta: BPK Gunung Mulia.

Kotler, P. 1999. Manajemen Pemasaran Analisis, Perencanaan, Implementasi, dan Pengendalian. Jilid ke-1. Edisi ke6. J. Wisaria, penerjemah. Jakarta: Erlangga.

Singarimbun, M, S. Effendi. 1995. Metode Penelitian Survei. Jakarta: LP3ES.

Siswono. 2001. Pemasaran Susu. Sumber: http/www.gizi.net.

Sugiono. 2000. Desain Penelitian. Bandung: Pressindo.

1 Alumni Program Studi Gizi Masyarakat dan Sumberdaya Keluarga, IPB

2 Staf Pengajar Departemen Ilmu Keluarga dan Konsumen, FEMA IPB 